\title{
Influence of probiotics on water quality in intensified Litopenaeus vannamei ponds under minimum-water exchange
}

\author{
Marwa A. Hassan ${ }^{1 *}\left(\mathbb{D}\right.$, Mustafa A. Fathallah², Mohamed A. Elzoghby ${ }^{2}$, Mohamed G. Salem² and \\ Mohamed S. Helmy²
}

\begin{abstract}
The effects of two probiotics on $\mathrm{NH}_{3}$ degradation, as well as the magnetic field (21.56 $\mathrm{m}$ tesla) on the germination and proliferation of Bacillus spores, were studied in-vitro. Additionally, the effect of these probiotics on water quality maintenance in Litopenaeus vannamei holding ponds was investigated. For $180 \mathrm{~min}, \mathrm{NH}_{3}$ degradation was assessed as follows: Set 1: ammonia-free tap water with $\mathrm{NH}_{3}$; Probiotic $\mathrm{A}\left(5 \times 10^{10}\right.$ viable Bacillus spores $\left./ \mathrm{g}\right)$ with $\mathrm{NH}_{3}$; Probiotic $\mathrm{B}$ (multi spp. $2 \times 10^{9} \mathrm{CFU} / \mathrm{g}$ ) with $\mathrm{NH}_{3}$; and Set 2: same as set 1 with $30 \mathrm{mg} \mathrm{L}^{-1} \mathrm{OM}$. The magnetic field was tested on Probiotic A $\left(3.5 \times 10^{7} \mathrm{CFU}\right)$ for $36 \mathrm{~h}$ in triplicate. In the presence of organic matter, both probiotics degrade $\mathrm{NH}_{3}$. The viable Bacillus count increased within $6 \mathrm{~h}$ of being exposed to the magnetic field, reaching its peak after $36 \mathrm{~h}$. Firstly, fifteen ponds (250,000 PL/acre) were investigated, then 360 water samples were collected from the same corresponding pond for 8 weeks, and subjected to T1: control; T2: Probiotic A $\left(0.007 \mathrm{~g} / \mathrm{m}^{3} / 2\right.$ weeks); T3: Probiotic B (0.03 g/ $\mathrm{m}^{3} / 2$ weeks). Both probiotics with TVC and $\mathrm{NH}_{3}$ demonstrated a negative correlation, on the other hand, they showed a significant $(\mathrm{P} \leq 0.01)$ improvement in $\mathrm{DO}$ and $\mathrm{pH}$. Overall, both probiotics were able to degrade $\mathrm{NH}_{3}$ and the magnetic field (21.56 $\mathrm{m}$ tesla) was efficient to improve the germination and proliferation of Bacillus spores in-vitro. Probiotics were also effective for reducing TVC and $\mathrm{NH}_{3}$ levels by increasing dissolved oxygen and $\mathrm{pH}$ in pond water.
\end{abstract}

Keywords: Water probiotics, Water quality, Unionized ammonia, Magnetic field

\section{Introduction}

Aquaculture is a major source of food and nutrition for millions of people globally, and it is essential to address the world's critical food demand (Low et al. 2017). As a result, intensive aquaculture to meet the demands of a rapidly growing population has been laden with challenges (Edwards 2015). Consequently, high stocking densities cause rapid deterioration of water quality, leading to stress and increased susceptibility to diseases as it is a suitable environment for the proliferation of pathogenic

\footnotetext{
*Correspondence: marwamenaem@vet.suez.edu.eg;

marwamenaem@yahoo.com

${ }^{1}$ Department of Animal Hygiene, Zoonoses and Behavior, Faculty of Veterinary Medicine, Suez Canal University, Ismailia 41522, Egypt Full list of author information is available at the end of the article
}

microbes, and, eventually, the mortality of cultured species (Lieke et al. 2019; Zokaeifar et al. 2014). Instantaneously, increased organic carbon, suspended particles, phosphates, nitrogenous species (nitrates, nitrites, and ammonia), chemical oxygen demand, and biological oxygen demand are frequently related to aquaculture effluent. Generally, water pollution in aquaculture is unavoidable since aquatic organism culture is accompanied by waste accumulation, which pollutes receiving waters and groundwater, moreover, aquaculture effluents are discharged into natural water bodies (Lalloo et al. 2007).

Water exchange and biofiltration are traditional approaches for controlling hazardous metabolites in aquaculture (Jahangiri and Esteban 2018), also several systems and methods for improving water quality and treating aquaculture wastewater have also been proposed 
and implemented which include recirculating aquaculture systems, biofloc technology, and aquaponics (Emerenciano et al. 2017; Maucieri et al. 2018; Rijn 2013). The most common approach for maintaining aquaculture water quality is frequent water exchange, which is costly, time-consuming, and may introduce pathogens into culture systems (Devaraja et al. 2013). Likewise, water scarcity and low water quality are becoming an international issue, particularly in arid and semi-arid regions; hence, the use of low-quality irrigation water is gaining importance in many countries around the world's agricultural sector (Aleman et al. 2014). Various researches are being conducted to investigate the efficacy of probiotics in the management of aquaculture water quality (Hura et al. 2018). Probiotics, in this context, can play a vital role in aquaculture productivity by improving non-specific disease prevention and providing pollution-free water sources (Panigrahi et al. 2010). Probiotics have been frequently proposed as environmentally friendly replacements to antibiotics (Jahangiri and Esteban 2018). Pond probiotics' antibacterial activity is mediated by variables such as the synthesis of bacteriocins, siderophores, lysozyme, protease, hydrogen peroxide, $\mathrm{pH}$ alterations, and the formation of organic acids and ammonia (Verschuere et al. 2000). Furthermore, in aquaculture systems, probiotics function through diverse mechanisms to eliminate organic wastes and contaminants because of the combination of 'bioremediation' and 'biocontrol' when dealing with environmental concerns. According to some findings, when probiotics were administered through the water compared to other administration protocols, a high level of integration of probiotic bacteria into treated aquatic organisms (especially in marine environments) was observed, possibly due to continuous drinking in the aquatic environment (Olafsen 2001; Villamil et al. 2010). The practical application and use of magnetic field treatments in agriculture have a wide range of applications, including seed germination, seedling development, and yields of various species, and poultry production, which plays an important role in addressing the shortage of nutrition in developing countries (Khalil et al. 2016). Similarly, magnetic treatment was revealed to enhance germination in Bacillus megaterium, Bacillus cereus, and Bacillus subtilis spores, and these spores' magnetic properties may have biotechnological applications, particularly in detection and separation (Zhou et al. 2018). Although the use of probiotics as water additives in ponds is thought to be more appropriate because it can be performed on all stages of fish (Jahangiri and Esteban 2018), Few studies have been conducted to investigate their use as water additives in fish production systems (Kord et al. 2022). There are few publications on the efficacy of probiotics and their comprehensive mechanism of action. Most researches are conducted in a laboratory setting; thus, the potentiality may differ when these probiotics are applied in natural settings (ponds and lakes) (Hasan and Banerjee 2020).

As a result, the current study was conducted to investigate the effects of two different probiotics used as water additives on $\mathrm{NH}_{3}$ degradation as well as the effect of a magnetic field on the germination and proliferation of Bacillus spores probiotic was studied in vitro. Furthermore, the effect of those probiotics on water quality in earthen ponds with Whiteleg shrimp (Litopenaeus vannamei) and a minimum-water exchange system.

\section{Materials and methods}

\section{Probiotics composition}

To conduct the study, the two most used probiotics in the field of aquaculture in Egypt were evaluated both in vitro and in pond treatment. Probiotic A (Sanolife PRO-W ${ }^{\circledR}$, INVE aquaculture Company, Thailand) is a single species probiotic of a total $5 \times 10^{10}$ viable spores per gram (B. subtilis, $2.75 \times 10^{10} \mathrm{CFU} / \mathrm{g}$ and B. licheniformi, $\left.2.25 \times 10^{10} \mathrm{CFU} / \mathrm{g}\right)$; the recommended dose is $0.007 \mathrm{~g} / \mathrm{m}^{3} / 2$ weeks (Total of $3.5 \times 10^{8} \mathrm{CFU} / \mathrm{g} / \mathrm{m}^{3}$ containing: B. subtilis, $1.93 \times 10^{8} \mathrm{CFU} / \mathrm{g}$ and $B$. licheniformi, $1.58 \times 10^{8} \mathrm{CFU} / \mathrm{g}$ ). While probiotic B (Aquastar ${ }^{\circledR}$, Biomin, Austria) is a mixture of probiotics consisting of Multi species with a total of $2 \times 10^{9} \mathrm{CFU} / \mathrm{g}$ (Bacillus spp., $5 \times 10^{8} \mathrm{CFU} / \mathrm{g}$; Pediococcus spp., 1.25-1.5 $\times 10^{9} \mathrm{CFU} / \mathrm{g}$; and Enterococcus spp., $5 \times 10^{7} \mathrm{CFU} / \mathrm{g}$ ); the recommended dose is $0.03 \mathrm{~g} / \mathrm{m}^{3} / 2$ weeks (Total of $6 \times 10^{7} \mathrm{CFU} / \mathrm{g} /$ $\mathrm{m}^{3}$ containing: Bacillus spp., $1.5 \times 10^{7} \mathrm{CFU} / \mathrm{g}$; Pediococcus spp., $4 \times 10^{7} \mathrm{CFU} / \mathrm{g}$; and Enterococcus spp., $\left.1.5 \times 10^{6} \mathrm{CFU} / \mathrm{g}\right)$.

\section{In vitro evaluation of probiotics on $\mathrm{NH}_{3}$ degradation}

In vitro trial for the effectiveness of both probiotics on reduction of $\mathrm{NH}_{3}$ was conducted at $25^{\circ} \mathrm{C}$ by dissolving ammonium chloride (APHA 2017) in ammonia-free tap water $(10 \mathrm{~L})$; $\mathrm{pH} 7.9 \pm 0.1$ with a final concentration of $1 \mathrm{mg} \mathrm{N}^{-1}$ and $1.22 \mathrm{mg} \mathrm{NH}_{3} \mathrm{~L}^{-1}$ into 2 sets, each designed in triplicates, the first set includes 3 treatments: T1; control (ammonia-free tap water with $\mathrm{NH}_{3}$ ); T2 (Probiotic A with $\mathrm{NH}_{3}$ ) and $\mathrm{T} 3$; (probiotic $\mathrm{B}$ with $\mathrm{NH}_{3}$ ); while the second set included T4; T5 and T6, which were designed just like the first set in addition to the presence of organic matter (30 $\mathrm{mg} \mathrm{L}^{-1} \mathrm{OM}$ ), which was selected based on a previously conducted survey (data are not shown). Yeast suspension (Lab018, United Kingdom) was added as a source of organic matter and was measured according to Kumar (1992). $\mathrm{NH}_{3}$ levels were measured at 30; 60; 120 and 180 min after initial addition. 


\section{In vitro evaluation of magnetic field on the propagation of Bacillus spores probiotic}

Single species probiotic was selected for easy culturing and counting. Evaluation of magnetic field on viable Bacillus spores of the probiotic was conducted on 2 systems of water tanks at $25{ }^{\circ} \mathrm{C}$, the first system served as control system supplied with aerators, that consisted of 3 tanks (1000 L capacity) and the second system without aerators and consisted of 3 tanks (1000 L capacity) with magnetic field system (magnet with a whole field strength of $21.56 \mathrm{~m}$ tesla divided into $10.78 \mathrm{~m}$ tesla in each side; control unite which disconnected the field every $3 \mathrm{~h}$. work for one hour rest; and water motor). A single spp. probiotic $0.7 \mathrm{~g}\left(3.5 \times 10^{10} \mathrm{CFU}\right)$ was dissolved in $1 \mathrm{~L}$ sterile saline $(0.85 \%)$ then $100 \mathrm{~mL}$ was added to each sterilized perchlorinated water tank $(100 \mathrm{~L})$ to final dose of $\left(3.5 \times 10^{7} \mathrm{CFU}\right)$. Water samples for viable spore bacillus count were collected after $3,6,12,24$, and $36 \mathrm{~h}$ post-application on $\mathrm{BHI}$ agar for $24 \mathrm{~h}$. at $30^{\circ} \mathrm{C}$ using drop plate technique (Herigstad et al. 2001).

\section{Evaluated ponds conditions}

This study was conducted to evaluate the efficiency of 2 types of probiotics in maintaining water quality in whiteleg shrimp (Litopenaeus vannamei) farm in East Delta, Egypt. This study was conducted on a farm with a total pond area of $3900 \mathrm{~m}^{2} /$ earthen pond filled with marine water. The water depth of about $1.8 \mathrm{~m}$ between June and August 2019. The post-larvae of white shrimp (L. vannamei) were obtained from a private hatchery in June. Ponds were dried for one month and the topsoil was scraped and removed, plowed, and filled with pre-chlorinated (12 ppm available chlorine) water from a reservoir pond. Aerators were deployed in each pond according to the stocking density of the pond at the rate of one paddlewheel aerator (1 HP motor) for 1-hectare post larvae (PL).

Each pond was stocked with whiteleg shrimp (L. vannamei) at the rate of $250,000 \mathrm{PL} /$ acre with an average initial weight $0.005 \mathrm{~g}$. A good quality high protein (38\%) commercial feed from Skretting Egypt Company (Table 1) was provided 3 times a day as per the feeding schedule given by the feed manufacturer.

Productivity was based on the natural productivity of the ponds hence the experimental ponds were kept free from any shading throughout the day. A total of 15 ponds were used in this investigation, which were examined for water parameters before the conduction of the study ( $\mathrm{n}=45$ water samples), after that, a total of 360 water samples ( $\mathrm{n}=120$ sample/5 ponds/treatment) were collected from the same corresponding pond during the study period of 8 weeks and the ponds were classified
Table 1 Proximate composition (\% dry matter) of the diet

\begin{tabular}{lc}
\hline Items & $\%$ \\
\hline Moisture & 7.45 \\
Crude protein & 37.92 \\
lipid & 6.5 \\
Crude Ash & 9.7 \\
NFE & 45.88 \\
Gross energy & 440.65 \\
\hline
\end{tabular}

Based on NRC (1993) for protein, lipid and carbohydrate respectively

into 3 treatments (5 pond/treatment); T1: the control ponds; T2: ponds treated with single spp. probiotic; T3: ponds treated with multi spp. probiotic.

\section{In pond probiotics evaluation on water quality}

Two different probiotic brands were added to ponds' water every 2 weeks, besides the control ponds with no probiotic. In the control ponds (T1) water exchange rate was one-third of the pond's water every 3 days, while in the other treated ponds the following strategy was applied: in T2: water in ponds was not exchanged for 7 days after the first use $(50 \mathrm{~g} /$ pond) of the probiotic ( 2 days before PL stocking and 5 days after), every 2 weeks the probiotic was applied into the ponds which were closed for 5 consecutive days, in T3 the ponds were closed for 10 days after application $(200 \mathrm{~g} /$ pond) of the probiotic ( 5 days before PL stocking and 5 days after), then water exchange rate in each treatment was applied every 2 weeks as one-third of the pond's water. Sampling for physicochemical parameters was collected from specific points of the pond at a depth of $50 \mathrm{~cm}$ below the surface. Temperature, $\mathrm{pH}$ using (Jenway, 370- $\mathrm{pH}$ meter, $\mathrm{U} . \mathrm{K})$ and $\mathrm{DO}\left(\mathrm{mg} \mathrm{L}^{-1}\right)$ by dissolved oxygen meter (DOmeter; Crison OXI 45 P, EU), salinity $\left(\mathrm{g} \mathrm{L}^{-1}\right)$, by conductivity meter (Jenway, 4520 conductivity meter, UK) were measured onsite daily, according to the standard procedures and methods as defined in APHA (2017). OM $\left(\mathrm{mg} \mathrm{L}^{-1}\right)$ according to (Kumar 1992), and toxic ammonia $\left(\mathrm{NH}_{3}\right)\left(\mathrm{mg} \mathrm{L}^{-1}\right)$ were analyzed spectrophotometrically at weekly intervals (Thermo Spectra, USA) following standard procedures (APHA 2017). Water samples for the total Vibrio count (TVC) were collected weekly and serially diluted and plated on TCBS medium (Hi-media, Mumbai) for $24-48 \mathrm{~h}$ at $30{ }^{\circ} \mathrm{C}$ using the drop plate technique described by (Herigstad et al. 2001).

\section{Statistical analysis}

The data were statistically analyzed using SPSS version 22 computer program (Inc., 1989-2013), results were expressed as means $\pm \mathrm{SE}$ for each treatment and were subjected to one way ANOVA analysis of variance LSD 
test performed to test the significant difference between the treatments at $P \leq 0.01$ and $P \leq 0.05$. The Pearson correlation coefficient was performed as a correlation matrix in the form of a rectangular array of numbers, which gives the correlation coefficient of the variables with each other. Factor analysis was performed as principal components analysis (PCA) according to the method described by Liu et al. (2003), to summarize the major relationship between variables by showing distribution and variation within the physicochemical, KMO and Bartlett's sphericity test were used to verify the applicability of PCA to raw data (Zhang et al. 2020). Then, the corresponding correlation coefficient matrix, and eigenvalues were calculated. The principle that the eigenvalue $>1.0$ to determine the number of principal components was accepted (Mandal et al. 2008). The maximum variance was used to normalize the rotation of the original data to rotate the factor using Varimax with Kaiser normalization (Kaiser 1958).

\section{Results}

\section{Effect of probiotics on $\mathrm{NH}_{3}\left(\mathrm{mg} \mathrm{L}^{-1}\right)$}

Treatment with single spp. probiotic positively enhanced the significant $(\mathrm{P} \leq 0.01)$ reduction in $\mathrm{NH}_{3}$ level during the different experimental time compared to control with higher reduction percentage; the effect of multi spp. probiotic was shown as a trend toward a decrease in the level of $\mathrm{NH}_{3}$ when compared to the control group. Regarding the effect in the presence of OM, both probiotics showed a significant decrease in $\mathrm{NH}_{3}$ level $(\mathrm{P} \leq 0.01)$ compared to control; maximum reduction effect $(\mathrm{P} \leq 0.01)$ in single spp. probiotic was pronounced than the mixture of probiotics within 60 and 120 min (Fig. 1).

\section{Effect of magnetic field on Bacillus spores probiotic}

The effect of magnetic field (21.56 m Tesla) on Bacillus spores was evaluated and data is illustrated in Fig. 2, the first detection of the viable cell count in magnetic field treatment was recorded $6 \mathrm{~h}$ after application and the count was gradually elevated with the increasing time, one the other hand, after $36 \mathrm{~h}$ Bacillus were detected in the control system with significantly $(P \leq 0.0001)$ lower count compared to magnetic field application.

\section{Total Vibrio count $\left(\log _{10} \mathrm{CFU} \mathrm{mL} \mathrm{L}^{-1}\right)$ of water pond}

A significant $(\mathrm{P} \leq 0.01)$ decrease in TVC $\left(\log _{10} \mathrm{CFU}\right.$ $\mathrm{mL}^{-1}$ ) in both $\mathrm{T} 2$ and T3 was observed before and after treatment as well as when compared to control ponds (Table 2). TVC in control ponds (T1) correlated positively with temperature; $\mathrm{pH}$ and $\mathrm{NH}_{3}$ and negatively with salinity (Table 3 ). Both probiotics and TVC were found to have a significant $(\mathrm{P} \leq 0.01)$ negative correlation (Table 3).

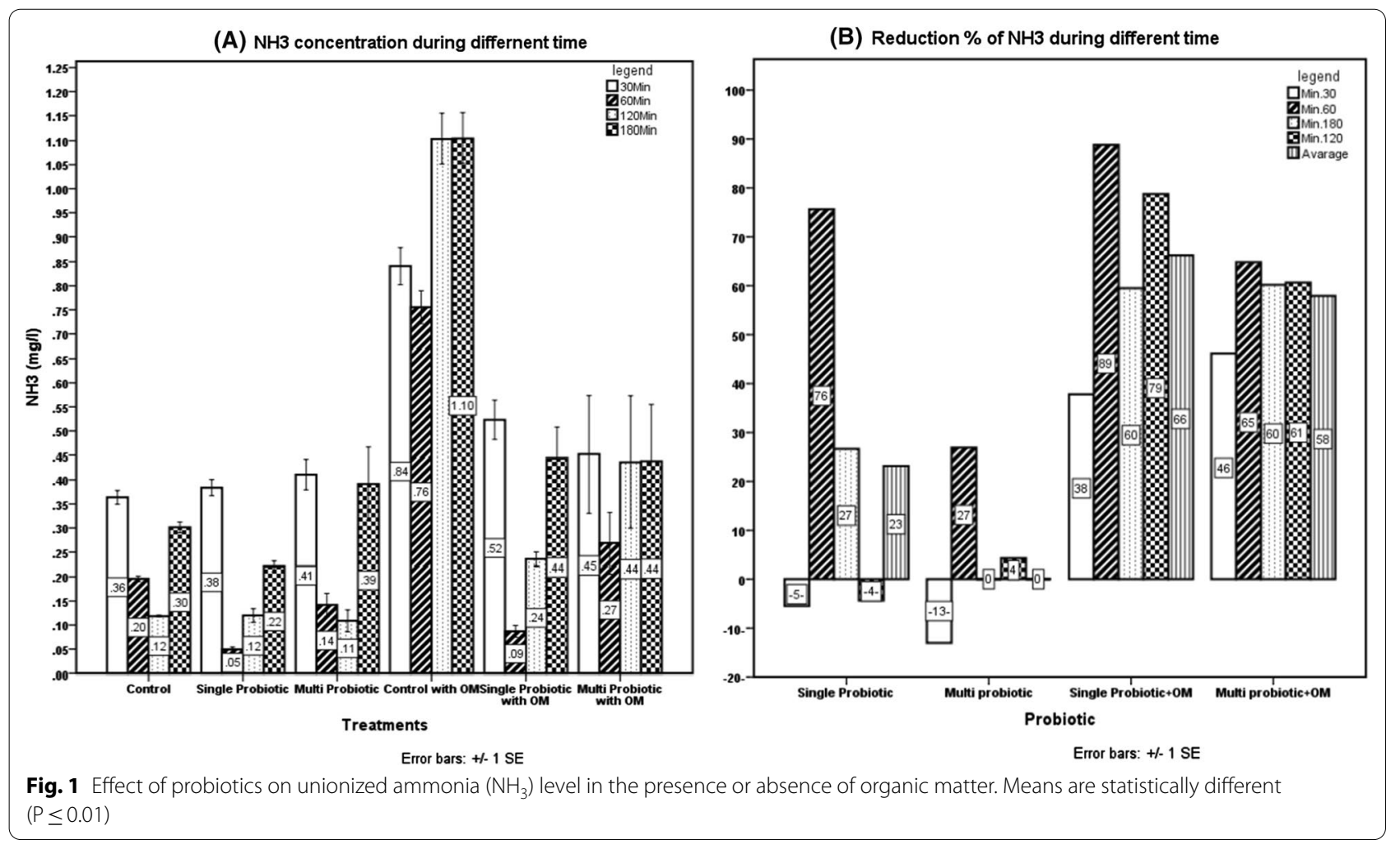




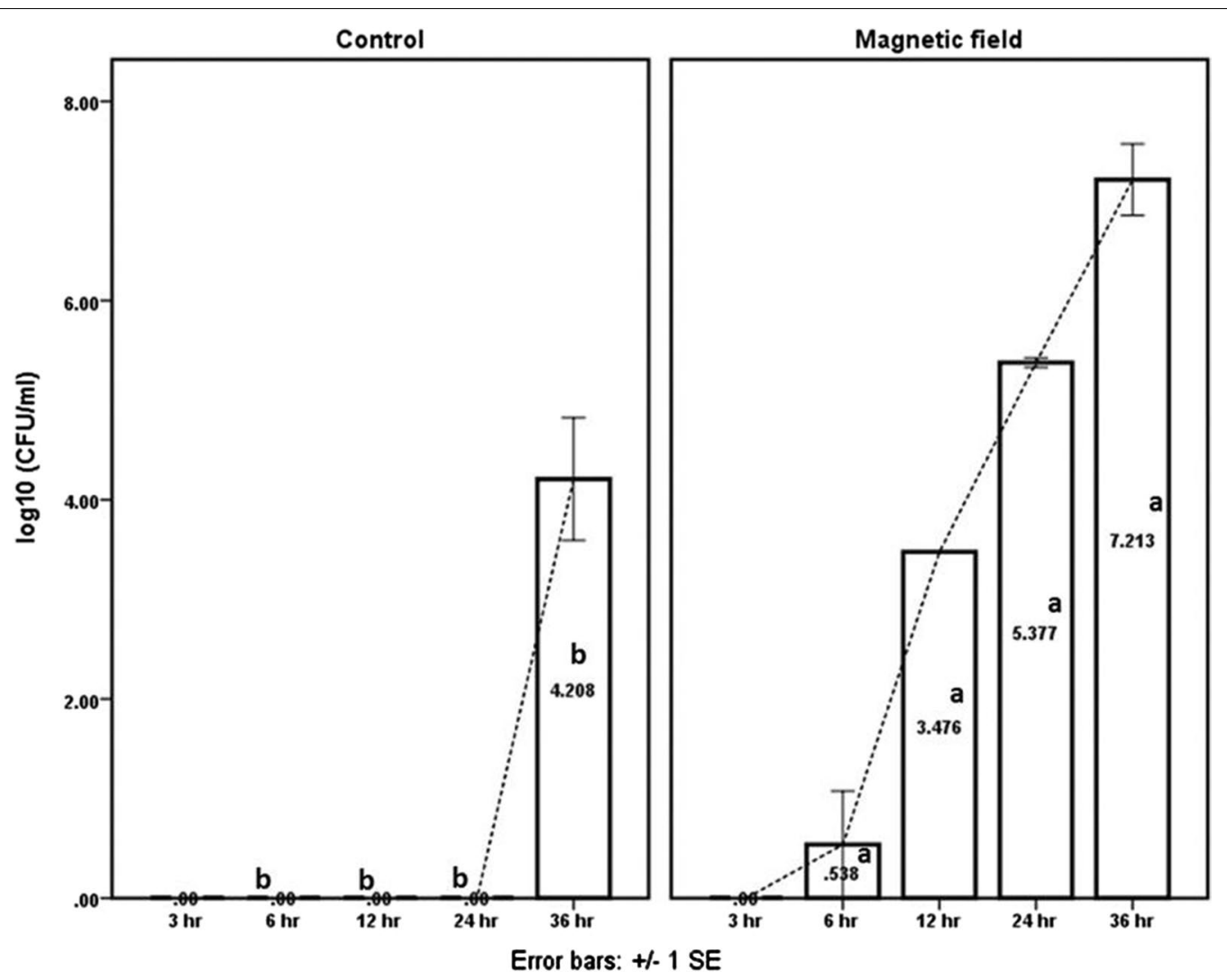

Fig. 2 Effect of magnetic field on Bacillus spore's germination and propagation. Means are different letters are significantly differing at $P \leq 0.0001$

\section{Water pond temperature $\left({ }^{\circ} \mathrm{C}\right)$ and dissolved oxygen} $\left(\mathrm{mg} \mathrm{L}^{-1}\right)$

Water temperature $\left({ }^{\circ} \mathrm{C}\right)$ showed almost the same pattern before and after the treatment with non-significant change among the treatments (Table 2).

Although the levels of dissolved oxygen (DO) $\mathrm{mg} \mathrm{L}^{-1}$ found a non-significant difference in all ponds before the application of probiotics to the water, the highest level of DO was recorded in T3 followed by T2 which was significantly different from the control ponds (Table 2). A significant $(\mathrm{P} \leq 0.01)$ positive relationship was observed between the level of $\mathrm{DO}$ in water with $\mathrm{T} 3$ and $\mathrm{T} 2$, (Table 3).

\section{Water pond salinity $\left(\mathrm{g} \mathrm{L}^{-1}\right)$ and $\mathrm{pH}$}

Regarding the water salinity $\left(\mathrm{g} \mathrm{L}^{-1}\right)$, a non-significant difference with a trend toward an increase in the treated ponds after treatment was recorded (Table 2). The $\mathrm{pH}$ of the ponds after treatment showed a significant decrease $(\mathrm{P} \leq 0.05)$ than that of the pretreatment, in addition, a significant $(\mathrm{P} \leq 0.05)$ decrease in the $\mathrm{pH}$ values was recorded in each of the ponds treated with probiotics, while $\mathrm{T} 2$ recorded the lowest significant $\mathrm{pH}(\mathrm{P} \leq 0.05)$ between treatments (Table 2). The $\mathrm{pH}$ value showed a strong negative correlation $(\mathrm{P} \leq 0.01)$ with both $\mathrm{T} 2$ and T3 (Table 3).

Organic matter $\left(\mathrm{mg} \mathrm{L}^{-1}\right)$ and Toxic ammonia $\mathrm{NH}_{\mathbf{3}}\left(\mathrm{mg} \mathrm{L}^{-1}\right)$ A significant decrease $(\mathrm{P} \leq 0.05)$ was reported in organic matter $(\mathrm{OM}) \mathrm{mg} \mathrm{L}^{-1}$ in the post-treated ponds with $\mathrm{T} 2$ and $\mathrm{T} 3$ than pre-treated ponds, and $\mathrm{T} 2$ also recorded the lowest values among the treatments (Table 2). $\mathrm{NH}_{3}$ levels behaved the same pattern as well as $\mathrm{pH}$ values in pre- and post-treated ponds, as well as in response to probiotics application (Table 2$)$. A highly significant $(\mathrm{P} \leq 0.01)$ inverse relationship between probiotic inT2 and OM has been reported (Table 3$)$. A negative correlation $(\mathrm{P} \leq 0.01)$ was observed between the use of both probiotics and $\mathrm{NH}_{3}$ (Table 3).

\section{Principal component analysis of water quality parameters}

Principal components analysis (PCA) was conducted as it is an effective tool to figure out the driving factors of water quality with probiotics effect in a deep sight. The parameters in all treatments produced three principal components (PC) explaining the total variances of 79.296\%, 75.457, and 77.092\% for T1; T2, and T3 respectively. Corresponding, variable loadings and explained 
Table 2 Some physicochemical parameters of the examined fish water ponds before and after application of probiotic

\begin{tabular}{|c|c|c|c|c|c|c|c|c|}
\hline \multirow{2}{*}{$\begin{array}{l}\text { Treatments } \\
\text { Application } \\
\text { to the pond }\end{array}$} & \multicolumn{2}{|c|}{ Control ponds (T1) } & \multicolumn{2}{|c|}{ Single spp. probiotic (T2) } & \multicolumn{2}{|c|}{ Multi spp. probiotic (T3) } & \multirow{2}{*}{\multicolumn{2}{|c|}{$\begin{array}{l}\text { Permissible limits } \\
\text { according to }\end{array}$}} \\
\hline & Before stocking & After stocking & $\begin{array}{l}\text { Before } \\
\text { stocking }\end{array}$ & $\begin{array}{l}\text { After } \\
\text { stocking }\end{array}$ & $\begin{array}{l}\text { Before } \\
\text { stocking }\end{array}$ & After stocking & & \\
\hline $\begin{array}{l}\text { Total Vibrio } \\
\text { count (log } \\
\text { CFU mL } \\
\text {-1) })^{*}\end{array}$ & $3.764^{b} \pm 0.129$ & $3.63^{b} \pm 0.137$ & $4.408^{a} \pm 0.173$ & $1.263^{c} \pm 0.193$ & $4.055^{\mathrm{ab}} \pm 0.213$ & $0.856^{\mathrm{C}} \pm 0.188$ & & \\
\hline $\begin{array}{l}\text { Temperature } \\
\left({ }^{\circ} \mathrm{C}\right)^{*}\end{array}$ & $29.019^{\mathrm{a}} \pm 0.123$ & $29.271^{a} \pm 0.229$ & $28.621^{\mathrm{a}} \pm 0.182$ & $29.068^{\mathrm{a}} \pm 0.1$ & $28.734^{\mathrm{a}} \pm 0.13$ & $29.068^{\mathrm{a}} \pm 0.095$ & $24-30$ & $\begin{array}{l}\text { (Clifford 1997; } \\
\text { Lucas and } \\
\text { Southgate } \\
\text { 2012) }\end{array}$ \\
\hline $\begin{array}{l}\text { Dissolved } \\
\text { oxygen } \\
\left(\mathrm{m} \mathrm{gL}^{-1}\right)\end{array}$ & $4.127^{d} \pm 0.078$ & $4.782^{c} \pm 0.102$ & $4.141^{d} \pm 0.077$ & $5.965^{b} \pm 0.431$ & $4.603^{c d} \pm 0.017$ & $6.541^{a} \pm 0.294$ & $>4$ & $\begin{array}{l}\text { Lucas and } \\
\text { Southgate } \\
\text { (2012) }\end{array}$ \\
\hline $\mathrm{pH}$ & $7.614^{b} \pm 0.059$ & $7.554^{b c} \pm 0.071$ & $7.903^{a} \pm 0.026$ & $6.995^{d} \pm 0.08$ & $7.917^{\mathrm{a}} \pm 0.017$ & $7.314^{c} \pm 0.056$ & $6.5-9.5$ & $\begin{array}{l}\text { Carbajal- } \\
\text { Hernández } \\
\text { et al. (2012) }\end{array}$ \\
\hline $\begin{array}{l}\text { Salinity } \\
\left(\mathrm{gL}^{-1}\right)\end{array}$ & $35.355^{\mathrm{ab}} \pm 1.499$ & $37.590^{\mathrm{a}} \pm 1.452$ & $31.690^{\mathrm{ab}} \pm 0302$ & $34.0^{\mathrm{ab}} \pm 0.533$ & $30.483^{b} \pm 0.128$ & $32.136^{\mathrm{ab}} \pm 0.519$ & $15-45$ & $\begin{array}{l}\text { (Clifford 1997; } \\
\text { Lucas and } \\
\text { Southgate } \\
\text { 2012) }\end{array}$ \\
\hline $\begin{array}{l}\text { Organic } \\
\text { matter } \\
\left(\mathrm{m} \mathrm{gL}^{-1}\right)\end{array}$ & $15.479^{b} \pm 0.216$ & $16.298^{\mathrm{ab}} \pm 0.194$ & $16.103^{b} \pm 0.229$ & $12.75^{c} \pm 0.665$ & $16.828^{a} \pm 0.141$ & $15.636^{b} \pm 0.626$ & & \\
\hline $\begin{array}{l}\mathrm{NH}_{3} \\
\left(\mathrm{~m} \mathrm{gL}^{-1}\right)\end{array}$ & $0.049^{a} \pm 0.003$ & $0.026^{b} \pm 0.001$ & $0.050^{a} \pm 0.004$ & $0.006^{\complement} \pm 0.001$ & $0.030^{b} \pm 0.002$ & $0.005^{c} \pm 0.0001$ & $0.01-0.09$ & $\begin{array}{l}\text { Boyd and } \\
\text { Zimmermann } \\
\text { (2000) }\end{array}$ \\
\hline
\end{tabular}

The means with different superscript letters within the same row for each parameter are significantly different at ${ }^{*} P \leq 0.01$ and at $P \leq 0.05$

Table 3 Correlations coefficient between different water quality parameters in the examined pond with or without probiotic

\begin{tabular}{|c|c|c|c|c|c|c|c|c|}
\hline Parameters & & \multirow{2}{*}{$\begin{array}{l}\begin{array}{l}\text { Total Vibrio } \\
\text { log (CFU } \\
\left.\mathrm{mL}^{-1}\right)\end{array} \\
-0.622^{* *}\end{array}$} & \multirow{2}{*}{$\begin{array}{c}\text { Temperature }\left({ }^{\circ} \mathrm{C}\right) \\
\mathbf{0 . 0 7 4}\end{array}$} & \multirow{2}{*}{$\begin{array}{l}\begin{array}{l}\text { Dissolved } \\
\text { oxygen } \\
\left(\mathrm{mg} \mathrm{L}^{-1}\right)\end{array} \\
0.536^{* *}\end{array}$} & \multirow{2}{*}{$\begin{array}{l}\mathrm{pH} \\
-0.452^{* *}\end{array}$} & \multirow{2}{*}{$\begin{array}{c}\text { Salinity }\left(\mathrm{g} \mathrm{L}^{-1}\right) \\
0.008\end{array}$} & \multirow{2}{*}{$\begin{array}{l}\begin{array}{l}\text { Organic } \\
\text { matter } \\
\left(\mathrm{mg} \mathrm{L}^{-1}\right)\end{array} \\
-0.451^{* *}\end{array}$} & \multirow{2}{*}{$\begin{array}{c}\mathrm{NH}_{3}\left(\mathrm{mg} \mathrm{L}^{-1}\right) \\
-0.472^{* *}\end{array}$} \\
\hline & Probiotics & & & & & & & \\
\hline $\begin{array}{l}\text { Total Vibrio log } \\
\left(\mathrm{CFU} \mathrm{mL}^{-1} \text { ) }\right.\end{array}$ & $-0.688^{* *}$ & 1 & 0.132 & $-0.348^{* *}$ & $0.537^{* *}$ & $-0.324^{* *}$ & $0.269^{* *}$ & $0.511 * *$ \\
\hline Temperature $\left({ }^{\circ} \mathrm{C}\right)$ & 0.040 & 0.127 & 1 & -0.066 & 0.028 & 0.031 & $-0.384^{* *}$ & 0.021 \\
\hline $\begin{array}{l}\text { Dissolved oxygen } \\
\left(\mathrm{mg} \mathrm{L}^{-1}\right)\end{array}$ & $0.708^{* *}$ & $-0.480^{* *}$ & -0.057 & 1 & $-0.354^{* *}$ & $0.304 * *$ & $-0.373^{* *}$ & $-0.604^{* *}$ \\
\hline $\mathrm{pH}$ & $-0.289^{* *}$ & $0.472^{* *}$ & 0.025 & $-0.180^{*}$ & 1 & $-0.584^{* *}$ & $0.301^{* *}$ & $0.527^{* *}$ \\
\hline Salinity $\left(\mathrm{g} \mathrm{L}^{-1}\right)$ & -0.049 & $-0.262^{* *}$ & 0.034 & $0.253^{* *}$ & $-0.612^{* *}$ & 1 & -0.070 & $-0.549 * *$ \\
\hline $\begin{array}{l}\text { Organic matter } \\
\left(\mathrm{mg} \mathrm{L}^{-1}\right)\end{array}$ & -0.037 & 0.116 & $-0.447^{* *}$ & $0.154^{*}$ & 0.098 & -0.070 & 1 & 0.129 \\
\hline $\mathrm{NH}_{3}\left(\mathrm{mg} \mathrm{L}^{-1}\right)$ & $-0.498^{* *}$ & $0.554^{* *}$ & 0.032 & $-0.659^{* *}$ & $0.476^{* *}$ & $-0.511^{* *}$ & -0.086 & 1 \\
\hline \multicolumn{9}{|c|}{ Control (non treated ponds) } \\
\hline \multicolumn{2}{|c|}{ Total Vibrio log (CFU mL ${ }^{-1}$ ) } & 1 & $0.255^{* *}$ & -0.112 & $0.424^{* *}$ & $-0.431^{* *}$ & 0.055 & $0.315^{* *}$ \\
\hline \multicolumn{2}{|l|}{ Temperature $\left({ }^{\circ} \mathrm{C}\right)$} & & 1 & -0.056 & 0.039 & 0.031 & $-0.488^{* *}$ & 0.062 \\
\hline \multicolumn{2}{|c|}{ Dissolved oxygen $\left(\mathrm{mg} \mathrm{L}^{-1}\right)$} & & & 1 & 0.033 & $0.545^{* *}$ & 0.048 & $-0.651^{* *}$ \\
\hline \multicolumn{2}{|l|}{$\mathrm{pH}$} & & & & 1 & $-0.677^{* *}$ & 0.062 & $0.405^{* *}$ \\
\hline \multicolumn{2}{|l|}{ Salinity $\left(\mathrm{g} \mathrm{L}^{-1}\right)$} & & & & & 1 & -0.085 & $-0.6211^{* *}$ \\
\hline \multicolumn{2}{|c|}{ Organic matter $\left(\mathrm{mg} \mathrm{L}^{-1}\right)$} & & & & & & 1 & -0.156 \\
\hline \multicolumn{2}{|l|}{$\mathrm{NH}_{3}\left(\mathrm{mg} \mathrm{L}^{-1}\right)$} & & & & & & -0.156 & 1 \\
\hline
\end{tabular}

Probiotics: upper diagonal represents single spp. and lower one represents multi spp.

${ }^{*}$ Correlation is significant at the 0.05 level (2-tailed)

**Correlation is significant at the 0.01 level (2-tailed) 
variance are presented in Table 4. PC1 in T1 had positive loadings ( $>0.75$ ) on DO and significant negative loadings with $\mathrm{NH}_{3}$; $\mathrm{PC} 2$ was characterized by strong positive loadings of TVC, and $\mathrm{pH}$; weak loading with $\mathrm{NH}_{3}$ and negative loading with salinity; PC3 showed a high positive loading of temperature. Regarding the effect of probiotics, PC1 in T2 was saturated mainly by high and moderate negative loads of probiotic and DO, respectively; on the other hand, high positive loading of TVC; and moderate for $\mathrm{NH}_{3}$ and weak for $\mathrm{pH}$ and $\mathrm{OM}$ was recorded. PC1 in T3 is mainly affected by a high positive load of probiotic; DO and high negative loads with TVC; $\mathrm{NH}_{3}$ and $\mathrm{pH}$.

\section{Discussion}

In vitro evaluation of the capability of the used probiotics in $\mathrm{NH}_{3}$ degradation was conducted either with or without OM; the result revealed that both probiotics reduced $\mathrm{NH}_{3}$ in the presence of high OM $\left(30 \mathrm{mg} \mathrm{L}^{-1}\right)$ which simulates the pond conditions. And this result proves the ability of probiotics in degradation of $\mathrm{NH}_{3}$ in presence of OM, meanwhile, multi spp. probiotics take more time due to the various composed microorganisms. According to Mahardhika et al. (2019), they indicated that Lactobacillus spp. and Bacillus spp. can inhibit the chemical reaction of the ammonia formation between uric acid and water and the uricase enzyme from gram-negative bacteria, such as most bacteria that conduct the nitrifying process originated from Nitrobacter, Nitrosomonas, and Nitrococcus. Additionally, the toxic ammonia had been reported to be degraded by Bacillus substilis (Cha et al. 2013), Bacillus amyloliquefaciens (Xie et al. 2013), Bacillus coagulans, and Lactobacillus plantarum (Mi et al. 2019). Moreover, Anwar et al. (2021) conducted a study to screen bacteria having a capacity to degrade ammonia as $\mathrm{NH}_{4} \mathrm{Cl}$ in vitro using 5 bacterial strains $(I B P-1, I B P-2$, $I B P-3, I B P-4$, and $I B P-5$ strains) and they found that the five bacterial isolates were able to degrade the ammonia content.

In natural conditions, probiotics should be introduced to the pond 2-7 days before aquatic animal stocking for activation, which varies depending on the type of probiotics spp.; to shorten this period, single spp. (Bacillus) probiotics were chosen to investigate the prospective influence of magnetic field on spore germination. Magnetic field exposure increased the number of viable $\mathrm{Bacil}$ lus count within $6 \mathrm{~h}$, with the maximum effect at $36 \mathrm{~h}$. One possible explanation for the magnetic field effect is that it promotes germination by enhancing their environment as a physical mean of treatment and regulating the quorum sensing process. Spore germination is typically stimulated by (i) nutrition such as sugars, purine nucleosides, and amino acids, (ii) non-nutrient agents such as CaDPA, surfactants, or dodecylamine, or (iii) physical treatments (Paidhungat et al. 2001; Setlow 2014). Germination, which is primarily characterized by spore rehydration and resistance loss, is only the very first stage in the process leading to the initiation of the first cell division and the establishment of a daughter population (Bressuire-Isoard et al. 2018). Xu Zhou et al. (2018) observed that Bacillus spores are paramagnetic because of the high manganese content accumulated within the spore core and that linked with the sport coat; and the intrinsic magnetic strength of the spore was adequate to facilitate their separation using relatively strong magnetic fields. Furthermore, Bacillus germination is a highly coordinated process that is controlled by quorum sensing and a cell-cell communication mechanism (Liu et al. 2016). Bacteria can count their numbers and regulate their activities by detecting the signaling molecules that

Table 4 Principal component analysis of the treatments with water quality parameters

\begin{tabular}{|c|c|c|c|c|c|c|c|c|c|}
\hline \multirow{2}{*}{$\frac{\text { Treatments }}{\text { Component }}$} & \multicolumn{3}{|c|}{ Control (non-treated ponds) } & \multicolumn{2}{|c|}{ Single spp. probiotic } & \multicolumn{4}{|c|}{ Multi spp. probiotic } \\
\hline & 1 & 2 & 3 & 1 & 2 & 3 & 1 & 2 & 3 \\
\hline Probiotic effect & & & & -0.912 & -0.004 & 0.163 & 0.949 & 0.058 & -0.091 \\
\hline Total Vibrio log (CFU mL $\left.{ }^{-1}\right)$ & -0.054 & 0.778 & 0.149 & 0.727 & 0.321 & 0.112 & -0.755 & 0.316 & 0.04 \\
\hline Temperature $\left({ }^{\circ} \mathrm{C}\right)$ & 0.044 & 0.179 & 0.872 & 0.148 & -0.036 & 0.911 & -0.016 & 0.041 & -0.836 \\
\hline Dissolved oxygen $\left(\mathrm{mg} \mathrm{L}^{-1}\right)$ & 0.941 & 0.082 & -0.033 & -0.681 & -0.298 & 0.065 & 0.842 & -0.123 & 0.143 \\
\hline $\mathrm{pH}$ & -0.145 & 0.874 & -0.078 & 0.448 & 0.704 & -0.058 & -0.242 & 0.828 & 0.056 \\
\hline Salinity $\left(\mathrm{g} \mathrm{L}^{-1}\right)$ & 0.663 & -0.635 & 0.142 & 0.014 & -0.954 & 0.038 & 0.023 & -0.922 & -0.021 \\
\hline Organic matter $\left(\mathrm{mg} \mathrm{L}^{-1}\right)$ & 0.104 & 0.13 & -0.852 & 0.493 & 0.004 & -0.718 & 0.021 & 0.086 & 0.866 \\
\hline $\mathrm{NH}_{3}\left(\mathrm{mg} \mathrm{L}^{-1}\right)$ & -0.813 & 0.386 & 0.117 & 0.541 & 0.678 & 0.056 & -0.663 & 0.575 & -0.107 \\
\hline Initial Eigenvalues & 2.024 & 1.976 & 1.55 & 2.582 & 2.059 & 1.395 & 2.68 & 1.993 & 1.494 \\
\hline$\%$ of variance & 28.921 & 28.234 & 22.141 & 32.279 & 25.736 & 17.441 & 33.497 & 24.918 & 18.677 \\
\hline Cumulative \% & 28.921 & 57.155 & 79.296 & 32.279 & 58.016 & 75.457 & 33.497 & 58.415 & 77.092 \\
\hline
\end{tabular}


are generated when the concentration of the signaling molecules exceeds certain thresholds (Bassler and Losick 2006). According to Zhang et al. (2011), communication between endospores occurs during germination, with closer endospores eliciting more synchronized behavior.

The mechanism by which Bacillus spore germination could be improved, as well as the hatchability of Artemia as a live feed of shrimp, as magnetic fields can affect membrane functions, not only by a local effect on ion fluxes or ligand binding but also by altering the distribution and aggregation of intramembranous proteins (Bersani et al. 1997).

Microorganisms in intensive aquaculture play a key role in influencing productivity, nutrient cycling, disease outbreaks, and environmental protection (Moriarty and Decamp 2005). Vibrio is a common bacteria found in a variety of aquatic and marine ecosystems; of the more than 100 Vibrio species discovered, approximately 12 types can cause human infections, while others cause diseases in marine animals (Huang et al. 2021). In general, dissolved organic carbon (DOC) has been shown to have a significant impact on Vibrio ecology (Takemura et al. 2014). Furthermore, Vibrio spp. are obligate heterotrophs that depend on organic matter for carbon sources and use a variety of them for nutrition; additionally, Vibrio spp. may integrate, consume, and produce organic matter, altering its chemical characteristics and bioavailability (Zhang et al. 2018). In the current study, both probiotics significantly reduced TVC, with a negative correlation, and this finding could be supported by research published by Kord et al. (2022), who indicated that the use of multiple probiotic species as water additives in Tilapia production may combat TVC abundance and prevent the occurrence of fish diseases. Simultaneously, (Xu Zhou et al. 2018) discovered that utilizing Bacillus spp. probiotics in a water pond reduced the presence of Vibrio harveyi, Vibrio vulnificus, Vibrio parahemolyticus, and Vibrio vulnificus.

The most reasonable explanation is that probiotics actively assimilate or break down organic matter or toxic material, hence improving environmental quality (Hemaiswarya and Doble 2013). Gram-positive Bacillus spp. convert organic matter back to $\mathrm{CO}_{2}$ more efficiently than gram-negative bacteria, which convert a higher amount of organic carbon to bacterial biomass or slime (Stanier et al. 1963), gram-positive bacteria in the production pond can decrease dissolved and particulate organic carbon buildup during the culture cycle while enhancing more stable phytoplankton blooms through increased $\mathrm{CO}_{2}$ production (Scura 1995). At the same time, probiotics synthesize more enzymes than natural bacteria, including amylase, protease, lipase, xylanase, and cellulase, which aid in waste decomposition (Araujo et al. 2016; Banerjee et al. 2017; Giri et al. 2013). The water quality parameters indicated that alkaline $\mathrm{pH}$ conditions, as well as elevated temperature and ammonia levels, favor the emergence of high Vibrio counts (Heenatigala and Fernando 2016; Hsieh et al. 2008). Furthermore, TVC had a proper relationship with $\mathrm{pH}, \mathrm{NH}_{3}$ and temperature in control ponds, but this relationship was inverted with the addition of probiotics, which improved water quality while making it unfavorable for Vibrio proliferation. Douillet (1998) observed that a probiotic additive composed of a mixture of bacteria in a liquid suspension improved water quality in fish and crustacean cultures by lowering the concentration of $\mathrm{OM}$ and ammonia, which was accomplished by a series of enzymatic processes carried out in sequence by the different strains present in the probiotic mixture, as a result, the addition of this blend improved water quality.

The physicochemical parameters of pond water are vital determinants of water quality and a culture system's ability to support fish production (Kord et al. 2022). The levels of all water physicochemical parameters obtained in this study were within the acceptable limits for shrimp culture (Boyd and Zimmermann 2000; Carbajal-Hernández et al. 2012; Clifford 1997; Lucas and Southgate 2012; Reddy and Mounika 2018).

The data obtained showed no variation in water temperature among treatments, which is consistent with the findings of several authors (Banerjee et al. 2010; Ghosh et al. 2008; Nimrat et al. 2012) who found no significant impact of Bacillus species on temperature. According to Velmurugan and Rajagopal (2009), the temperature may be unaffected by a biological activity because it is a conservative measure.

DO particularly is a very critical water quality parameter that supports all living things including fish (Kord et al. 2022). DO levels in the present study were significantly enhanced by the different probiotics microorganism species used as water additives. A few studies have found that Bacillus probiotic can keep DO levels in the optimal range. Higher DO values were obtained in an experiment conducted by Hura et al. (2018) who investigate the influence of Bacillus megaterium on water quality in the cultivation of major carps. A blend of Bacillus species improved DO levels in an aquarium filled with tilapia larvae at high density (Hainfellner et al. 2018). Higher DO was documented in Bacillus supplemented waters during transport of fish (Yellowfin Tuna Yolk Sac Larvae and Carnegiella strigata) in additional tests utilizing Bacillus species (B. subtilis, Bacillus licheniformis, B. megaterium, and Bacillus laterosporous) (Gomes et al. 2008; Zink et al. 2011). Nevertheless, no significant difference in DO levels was seen when a mixture of B. megaterium and Streptomyces fradiae was used for 
water treatment (Kord et al. 2022). It may be argued that research on the modulation of DO by probiotic Bacillus is less investigated when compared to its effects on nitrogenous species in aquaculture (Hlordzi et al. 2020). Furthermore, Nitrifies, Sulphur bacteria, Bacillus spp., Pseudomonas spp., Bacillus spp., Bacillus toyoi, Streptomyces (Das et al. 2008); Lactobacillus plantarum, Lactobacillus casei (Melgar Valdes et al. 2013) as water probiotics could enhance dissolve oxygen concentration.

The current study proposes that both probiotics added to the ponds' water correlated negatively with $\mathrm{pH}$, resulting in a significant reduction in its value, which was not online with the findings of Kord et al. (2022), who observed that different probiotics added to the Nile Tilapia ponds' water did not affect the $\mathrm{pH}$ value. The concentration of hydrogen ions $(\mathrm{pH})$ and alkalinity have an impact on practically every biological and chemical process, making them critical water quality factors (Summerfelt et al. 2015).

Considering, the effect of water probiotics on salinity modulation was not statistically significant. Because salinity is a conservative metric for water quality, biological processes have a challenging time modifying it (Velmurugan and Rajagopal 2009). Bacillus species have no significant effect on salinity as a water quality indicator, according to the limited study that has been conducted. Salinity, for example, was unaffected by B. pumilus (Banerjee et al. 2010; Sreenivasulu et al. 2016) or a mixture of B. megaterium and Streptomyces fradiae (Aftabuddin et al. 2013; Banerjee et al. 2010).

The current investigation revealed that the Bacillus spp. probiotic (T2) had the lowest OM concentration with a significant negative correlation between them. Gram-positive genus Bacillus group is more efficient than gram-negative genus in converting organic matter to $\mathrm{CO}_{2}$, it is suggested that maintaining high levels of probiotics in production ponds will reduce the accumulation of dissolved and particulate organic carbon during the growing season (Raja 2015), in addition, this can balance phytoplankton production (Balcázar et al. 2006). Previous research found that Bacillus spp. reduced organic matter loads in treated ponds compared to controls, resulting in higher water quality (Moriarty and Decamp 2005). Bacterial species belonging to the genera Bacillus, Pseudomonas, Nitrosomonas, Nitrobacter, Acinetobacter, and Cellulomonas are known to help in the mineralization of organic water and in reducing the accumulation of organic loads (Shariff et al. 2001).

In this study, the use of both probiotics resulted in a significant reduction in water $\mathrm{pH}$ and, as a result, $\mathrm{NH}_{3}$ levels, and this association was confirmed by the strong negative correlation between probiotics and both $\mathrm{pH}$ and $\mathrm{NH}_{3}$. This decrease in $\mathrm{NH}_{3}$ levels compared to the control group is consistent with those obtained by Kord et al. (2022), who reported a significant decrease in $\mathrm{NH}_{3}$ with the application of different probiotics into Nile Tilapia water ponds, and attributed this to the enhanced microbial activity that absorbed the nitrogenous compounds and used them in their metabolism. Furthermore, introducing probiotics to pond water may have enhanced the population of nitrifying bacteria, allowing ammonia to be converted to nitrite and subsequently to nitrate. This was consistent with the findings of (Wang et al. 2005), who discovered that adding probiotics to shrimp ponds significantly increased the population of nitrifying bacteria Nitrosomonas and Nitrobacter. Ammonia levels in shrimp water ponds can be reduced by introducing probiotics, according to (Wang 2007). The addition of the following probiotics resulted in $\mathrm{NH}_{3}$ reduction: Bacillus species (Bacillus subtilis, Bacillus licheniformis, Bacillus megaterium, and Bacillus laterosporous) (Gomes et al. 2008; Zink et al. 2011); Lactobacillus acidophilus (Porubcan 1991); Bacillus NL110 (Mujeeb Rahiman et al. 2010); Lactobacillus acidophilus (Khademzade et al. 2020; Porubcan 1991) discovered that adding Pediococcus acidilactici and Bacillus cereus bacteria to fishponds significantly reduced nitrogenous particles. (El-Kady et al. 2021) found also that commercial probiotics used as water additives reduced $\mathrm{NH}_{3}$ and total ammonia-nitrogen as compared to the control treatment.

Generally, water temperature, $\mathrm{pH}$, dissolved oxygen, and $\mathrm{NH}_{3}$ were improved in trials with probiotics, and daily administration of probiotics demonstrated the ability to maintain a healthy environment for shrimp and prawn larvae in the improved green water system (Banerjee et al. 2010).

In conclusion, the use of probiotics (single spp. or multi spp.) as water additives with minimum water exchange improved water quality by lowering TVC and $\mathrm{NH}_{3}$ levels and increasing DO levels. In-vitro testing of the ability of the applied probiotics in $\mathrm{NH}_{3}$ degradation demonstrated that both probiotics could reduce $\mathrm{NH}_{3}$ in the presence of high $\mathrm{OM}\left(30 \mathrm{mg} \mathrm{L}^{-1}\right)$, simulating pond conditions. Furthermore, in-vitro investigation of the influence of magnetic field on spore germination and proliferation revealed that magnetic field exposure increased the number of Bacillus spores within $6 \mathrm{~h}$, with the maximum effect at $36 \mathrm{~h}$, which will reduce the time required for activation of Bacillus spores' probiotics before stocking of PL. Further studies are needed to evaluate different magnetic fields strengths in aquaculture.

\section{Acknowledgements}

The authors thank Prof Dr Ahmed M Hassan who supported the work and reviewed and edited the manuscript 


\section{Authors' contributions}

All authors were collaborated in work planning, experimental design, measurement of parameters and writing the manuscript. All authors read and approved the final manuscript. MAH: methodology, investigation, formal analysis, validation, writing —original draft, writing — review and editing, visualization. MAF; MAE; MGS; MSH: methodology, measurement of water pond parameters, investigation, writing — original draft. All authors read and approved the final manuscript.

\section{Funding}

Open access funding provided by The Science, Technology \& Innovation Funding Authority (STDF) in cooperation with The Egyptian Knowledge Bank (EKB). This research did not receive any specific Grant from Funding agencies in the public, commercial, or not-for-profit sectors.

\section{Availability of data and materials}

The authors declare that they do not have any shared data available.

\section{Declarations}

Ethics approval and consent to participate

Not applicable.

\section{Consent for publication}

Not applicable.

\section{Competing interests}

The authors report no declarations of interest.

\section{Author details}

${ }^{1}$ Department of Animal Hygiene, Zoonoses and Behavior, Faculty of Veterinary Medicine, Suez Canal University, Ismailia 41522, Egypt. ${ }^{2}$ Fish Farming and Technology Institute, Suez Canal University, Ismailia 41522, Egypt.

Received: 8 January 2022 Accepted: 19 February 2022

Published online: 26 February 2022

\section{References}

Aftabuddin S, Kashem M, Kader M, Sikder M, Hakim M (2013) Use of Streptomyces fradiae and Bacillus megaterium as probiotics in the experimental culture of tiger shrimp Penaeus monodon (Crustacea, Penaeidae). Aquac Aquar Conserv Legis 6:253-267

Aleman El, Nbogholi A, Boix YF, Gonzalez-Olmedo J, Chalfun-Junior A (2014) Effects of EMFs on some biological parameters in coffee plants (Coffea Arabica L.) obtained by in vitro propagation. Polish J Environ Stud 23:95-101

Anwar K, Safitri R, Fajriani N, Gifari ZA, Wariata IW, Rosyidi A, Amin M, Ali M (2021) In Vitro screening of ammonia and nitrite-degrading bacteria isolated from broiler chicken (Gallus gallus domesticus) intestines and pond sediment of Nile tilapia (Oreochromis niloticus): a preliminary study. IOP Conf Ser Earth Environ Sci. https://doi.org/10.1088/1755-1315/913/1/ 012072

APHA (2017) Standard methods for the examination of water and wastewater. American Public Health Association, Washington

Araujo C, Munoz-Atienza E, Poeta P, Igrejas G, Hernandez PE, Herranz C, Cintas LM (2016) Characterization of Pediococcus acidilactici strains isolated from rainbow trout (Oncorhynchus mykiss) feed and larvae: safety, DNA fingerprinting, and bacteriocinogenicity. Dis Aquat Org 119(2):129-143

Balcázar JL, Blas ID, Ruiz-Zarzuela I, Cunningham D, Vendrell D, Múzquiz JL (2006) The role of probiotics in aquaculture. Vet Microbiol 114(3):173-186

Banerjee S, Khatoon H, Shariff M, Yusoff FM (2010) Enhancement of Penaeus monodon shrimp postlarvae growth and survival without water exchange using marine Bacillus pumilus and periphytic microalgae. Fish Sci 76(3):481-487

Banerjee G, Nandi A, Ray AK (2017) Assessment of hemolytic activity, enzyme production and bacteriocin characterization of Bacillus subtilis LR1 isolated from the gastrointestinal tract of fish. Arch Microbiol 199(1):115-124

Bassler B, Losick R (2006) Bacterially speaking. Cell 125(2):237-246
Bersani F, Marinelli F, Ognibene A, Matteucci A, Cecchi S, Santi S, Squarzoni S, Maraldi NM (1997) Intramembrane protein distribution in cell cultures is affected by $50 \mathrm{~Hz}$ pulsed magnetic fields. Bioelectromagnetics 18(7):463-469

Boyd C, Zimmermann S (2000) Freshwater prawn culture. Blackwell, Oxford, pp 221-238

Bressuire-Isoard C, Broussolle V, Carlin F (2018) Sporulation environment influences spore properties in Bacillus: evidence and insights on underlying molecular and physiological mechanisms. FEMS Microbiol Rev 42(5):614-626

Carbajal-Hernández JJ, Sánchez-Fernández LP, Carrasco-Ochoa JA, Martínez-Trinidad JF (2012) Immediate water quality assessment in shrimp culture using fuzzy inference systems. Expert Syst Appl 39(12):10571-10582

Cha J-H, Rahimnejad S, Yang S-Y, Kim K-W, Lee K-J (2013) Evaluations of Bacillus spp. as dietary additives on growth performance, innate immunity and disease resistance of olive flounder (Paralichthys olivaceus) against Streptococcus iniae and as water additives. Aquaculture 402:50-57

Clifford H (1997) Manual de operación para el manejo de super shrimp en estanques. Super Shrimp SA de CV. División de Servicios Técnicos, Spain

Das S, Ward LR, Burke C (2008) Prospects of using marine actinobacteria as probiotics in aquaculture. Appl Microbiol Biotechnol 81(3):419-429

Devaraja T, Banerjee S, Yusoff F, Shariff M, Khatoon H (2013) A holistic approach for selection of Bacillus spp. As a bioremediator for shrimp postlarvae culture. Turk J Biol 37:92-100

Douillet P (1998) Bacterial probiotic for water quality and disease control. World Aquaculture Society, Nevada

Edwards P (2015) Aquaculture environment interactions: past, present and likely future trends. Aquaculture 477:2-14

El-Kady AA, Magouz Fl, Mahmoud SA, Abdel-Rahim MM (2021) The effects of some commercial probiotics as water additive on water quality, fish performance, blood biochemical parameters, expression of growth and immune-related genes, and histology of Nile tilapia (Oreochromis nilotiCUS). Aquaculture 546:737249

Emerenciano MG, Martínez-Córdova LR, Martínez-Porchas M, Miranda-Baeza A (2017) Biofloc technology (BFT): a tool for water quality management in aquaculturein: water Quality. InTech, London

Ghosh S, Sinha A, Sahu C (2008) Bioaugmentation in the growth and water quality of livebearing ornamental fishes. Aquacult Int 16(5):393-403

Giri SS, Sukumaran V, Oviya M (2013) Potential probiotic Lactobacillus plantarum VSG3 improves the growth, immunity, and disease resistance of tropical freshwater fish, Labeo rohita. Fish Shellfish Immunol 34(2):660-666

Gomes LC, Brinn RP, Marcon JL, Dantas LA, Brandão FR, Sampaio de Abreu J, McComb DM, Baldisserotto B (2008) Using Efinol ${ }^{\circledR}$ L during transportation of marbled hatchetfish, Carnegiella strigata (Günther). Aquac Res 39(12):1292-1298

Hainfellner P, Cardozo M, Borzi M, Almeid AC, José L, Pizauro L, Schocken-Iturrino $R$, Costa G, dé Avila F (2018) Commercial probiotic increases survival rate and water quality in aquariums with high density of Nile tilapia larvae (Oreochromis niloticus). Int J Probiotics 13:139-142

Hasan KN, Banerjee G (2020) Recent studies on probiotics as beneficial mediator in aquaculture: a review. J Basic Appl Zool. https://doi.org/10.1186/ s41936-020-00190-y

Heenatigala P, Fernando M (2016) Occurrence of bacteria species responsible for Vibriosis in shrimp pond culture systems in Sri Lanka and assessment of the suitable control measures Sri Lanka. J Aquat Sci 21(1):1-17

Hemaiswarya S, Doble M (2013) Combination of phenylpropanoids with 5-fluorouracil as anti-cancer agents against human cervical cancer (HeLa) cell line. Phytomedicine 20(2):151-158

Herigstad B, Hamilton M, Heersink J (2001) How to optimize the drop plate method for enumerating bacteria. J Microbiol Methods 44(2):121-129

Hordzi V, Kuebutornye F, Afriyie G, Emmanuel A, Yishan L, Shuyan C, Melody A (2020) The use of Bacillus species in maintenance of water quality in aquaculture: a review. Aquac Rep 18:100503

Hsieh JL, Fries JS, Noble RT (2008) Dynamics and predictive modelling of Vibrio spp. in the Neuse River Estuary, North Carolina, USA. Environ Microbiol 10(1):57-64

Huang L, Fu Y, Sun W, Brzostek J (2021) Editorial: Vibrio virulence regulation and host interactions. Front Cell Infect Microbiol 11:793464 
Hura MU, Zafar T, Borana K, Prasad JR, lqbal J (2018) Effect of commercial probiotic Bacillus megaterium on water quality in composite culture of major carps. Int J Curr Agric Sci 8:268-273

Jahangiri L, Esteban MA (2018) Administration of probiotics in the water in finfish aquaculture systems: a review. Fishes 3:30-33

Kaiser HF (1958) The Varimax criterion for analytic rotation in factor analysis. Psychometrika 23:187

Khademzade O, Zakeri M, Haghi M, Mousavi SM (2020) The effects of water additive Bacillus cereus and Pediococcus acidilactici on water quality, growth performances, economic benefits, immunohematology and bacterial flora of whiteleg shrimp (Penaeus vannamei Boone, 1931) reared in earthen ponds. Aquac Res 51(5):1759-1770

Khalil MH, Shebl MK, Kosba MA, El-Sabrout K, Zaki N (2016) Estimate the contribution of incubation parameters influence egg hatchability using multiple linear regression analysis. Vet World 9(8):806

Kord MI, Maulu S, Srour TM, Omar EA, Farag AA, Nour AAM, Hasimuna OJ, Abdel-Tawwab M, Khalil HS (2022) Impacts of water additives on water quality, production efficiency, intestinal morphology, gut microbiota, and immunological responses of Nile tilapia fingerlings under a zerowater-exchange system. Aquaculture. https://doi.org/10.1016/jaquac ulture.2021.737503

Kumar D (1992) Fish culture in undrainable ponds: A manual for extension. $\mathrm{FAO}$, Rome

Lalloo R, Ramchuran S, Ramduth D, Görgens J, Gardiner N (2007) Isolation and selection of Bacillus spp. As potential biological agents for enhancement of water quality in culture of ornamental fish. J Appl Microbiol 103:1471-1479

Lieke T, Meinelt T, Hoseinifar SH, Pan B, Straus DL, Steinberg CE (2019) Sustainable aquaculture requires environmental-friendly treatment strategies for fish diseases. Rev Aquac. https://doi.org/10.1111/raq.12365

Liu C-W, Lin K-H, Kuo Y-M (2003) Application of factor analysis in the assessment of groundwater quality in a blackfoot disease area in Taiwan. Sci Total Environ 313(1-3):77-89

Liu X, Sun S, Ma B, Zhang C, Wan C, Lee D-J (2016) Understanding of aerobic granulation enhanced by starvation in the perspective of quorum sensing. Appl Microbiol Biotechnol 100(8):3747-3755

Low CF, Rozaini MZH, Musa N, Syarul Nataqain B (2017) Current knowledge of metabolomic approach in infectious fish disease studies. J Fish Dis 40(10):1267-1277

Lucas J, Southgate P (2012) Marine shrimp: aquaculture: farming aquatic animals and plants. Wiley-Blackwell, Chichester

Mahardhika B, Mutia R, Ridla M (2019) Efforts to reduce ammonia gas in broiler chicken litter with the use of probiotics. IOP Publishing, Bristol, p 012012

Mandal UK, Warrington D, Bhardwaj A, Bar-Tal A, Kautsky L, Minz D, Levy $G$ (2008) Evaluating impact of irrigation water quality on a calcareous clay soil using principal component analysis. Geoderma 144(1-2):189-197

Maucieri C, Nicoletto C, Junge R, Schmautz Z, Sambo P, Borin M (2018) Hydroponic systems and water management in aquaponics: a review. Ital J Agron. https://doi.org/10.4081/ija.2017.1012

Melgar Valdes CE, Barba Macías E, Álvarez-González CA, Tovilla Hernández C, Sánchez AJ (2013) Efecto de microorganismos con potencial probiótico en la calidad del agua y el crecimiento de camarón Litopenaeus vannamei (Decapoda: Penaeidae) en cultivo intensivo. J Rev Biol Trop 61:1215-1228

Mi J, Chen X, Liao X (2019) Screening of single or combined administration of 9 probiotics to reduce ammonia emissions from laying hens. Poult Sci 98(9):3977-3988

Moriarty D, Decamp O (2005) Probiotics in aquaculture. AQUA Culture Asia Pacific Magazine, China

Mujeeb Rahiman K, Jesmi Y, Thomas AP, Mohamed Hatha A (2010) Probiotic effect of Bacillus NL110 and Vibrio NE17 on the survival, growth performance and immune response of Macrobrachium rosenbergii (de Man). Aquac Res 41 (9):e120-e134

Nimrat S, Suksawat S, Boonthai T, Vuthiphandchai V (2012) Potential Bacillus probiotics enhance bacterial numbers, water quality and growth during early development of white shrimp (Litopenaeus vannamei). Vet Microbiol 159(3):443-450

NRC (1993) Nutrient requirements of fish. National Academies Press, Washington, DC
Olafsen JA (2001) Interactions between fish larvae and bacteria inmarine aquaculture. Aquaculture 200:223-247

Paidhungat M, Ragkousi K, Setlow P (2001) Genetic requirements for induction of germination of spores of Bacillus subtilis by $\mathrm{Ca}^{2+}$-dipicolinate. J Bacteriol 183(16):4886-4893

Panigrahi A, Kiron V, Satoh S, Watanabe T (2010) Probiotic bacteria Lactobacillus rhamnosus influences the blood profile in rainbow trout Oncorhynchus mykiss (Walbaum). Fish Physiol Biochem 36(4):969-977

Porubcan R (1991) Reduction of ammonia nitrogen and nitrite in tanks of Penaeus monodon using floating biofilters containing processed diatomaceous earth media pre-inoculated with nitrifying bacteria. World Aquaculture Society, Baton Rouge, pp 16-20

Raja S (2015) Beneficial and destructive effects of probiotics in aquaculture systems - a review. Int J Fish Aquat Stud 2:153-159

Reddy MH, Mounika K (2018) Determination and comparative study of water quality parameters in shrimp culture ponds. Int J Res Appl Sci Eng Technol 6(9):216-221

Scura ED (1995) Dry season production problems on shrimp farms in Central America and the Caribbean basin. World Aquaculture Society, San Diego, pp 200-213

Setlow P (2014) Spore resistance properties. Microbiol Spectr 2(5):11

Shariff M, Yusoff F, Devaraja T, Rao PS (2001) The effectiveness of a commercial microbial product in poorly prepared tiger shrimp, Penaeus monodon (Fabricius), ponds. Aquac Res 32(3):181-187

Sreenivasulu P, Suman Joshi D, Narendra K, Venkata Rao G, Krishna Satya A (2016) Bacillus pumilus as a potential probiotic for shrimp culture. Int J Fish Aquat Stud 4:107-110

Stanier RY, Boudoroff M, Adelberg EA (1963) The microbial world. PrenticeHall Inc., Englewood Cliffs

Summerfelt ST, Zühlke A, Kolarevic J, Reiten BKM, Selset R, Gutierrez X, Terjesen BF (2015) Effects of alkalinity on ammonia removal, carbon dioxide stripping, and system $\mathrm{pH}$ in semi-commercial scale water recirculating aquaculture systems operated with moving bed bioreactors. Aquacult Eng 65:46-54

Takemura AF, Chien DM, Polz MF (2014) Associations and dynamics of Vibrionaceae in the environment, from the genus to the population level. Front Microbiol 5:38

van Rijn J (2013) Waste treatment in recirculating aquaculture systems. Aquac Eng 53:49-56

Velmurugan S, Rajagopal S (2009) Beneficial uses of probiotics in mass scale production of marine ornamental fish. Afr J Microbiol Res 3:185-190

Verschuere L, Rombaut G, Sorgeloos P, Verstraete W (2000) Probiotic bacteria as biological control agents in aquaculture. Microbiology 64(4):655-671

Villamil L, Figueras A, Planas M, Novoa B (2010) Pediococcus acidilactici in the culture of turbot (Psettamaxima) larvae: administration pathways. Aquaculture 307:83-88

Wang Y-B (2007) Effect of probiotics on growth performance and digestive enzyme activity of the shrimp Penaeus vannamei. Aquaculture 269(1-4):259-264

Wang Y-B, Xu Z-R, Xia M-S (2005) The effectiveness of commercial probiotics in northern white shrimp Penaeus vannamei ponds. Fish Sci 71(5):1036-1041

Xie F, Zhu T, Zhang F, Zhou K, Zhao Y, Li Z (2013) Using Bacillus amyloliquefaciens for remediation of aquaculture water. Springer Plus 2(1):1-5

Xu Zhou K, lonescu A, Wan E, Ho YN, Barnes CHW, Christie G, Wilson DI (2018) Paramagnetism in Bacillus spores: opportunities for novel biotechnological applications. Biotechnol Bioeng 115(4):955-964

Zhang J, Garner W, Setlow P, Yu J (2011) Quantitative analysis of spatialtemporal correlations during germination of spores of Bacillus species. J Bacteriol 193(15):3765-3772

Zhang X, Lin H, Wang X, Austin B (2018) Significance of Vibrio species in the marine organic carbon cycle-a review. Sci China Earth Sci 61(10):1357-1368

Zhang X, Zhang Y, Zhang Q, Liu P, Guo R, Jin S, Liu J, Chen L, Ma Z, Ying L (2020) Evaluation and analysis of water quality of marine aquaculture area. Int J Environ Res Public Health 17(4):1446

Zink IC, Benetti DD, Douillet PA, Margulies D, Scholey VP (2011) Improvement of water chemistry with Bacillus probiotics inclusion during simulated transport of yellowfin tuna yolk sac larvae. N Am J Aquac 73(1):42-48 
Zokaeifar H, Babaei N, Saad CR, Kamarudin MS, Sijam K, Balcazar JL (2014) Administration of Bacillus subtilis strains in the rearing water enhances the water quality, growth performance, immune response, and resistance against Vibrio harveyi infection in juvenile white shrimp, Litopenaeus vannamei. Fish Shellfish Immunol 36:68-74

\section{Publisher's Note}

Springer Nature remains neutral with regard to jurisdictional claims in published maps and institutional affiliations.

\section{Submit your manuscript to a SpringerOpen ${ }^{\circ}$ journal and benefit from:}

- Convenient online submission

- Rigorous peer review

- Open access: articles freely available online

- High visibility within the field

- Retaining the copyright to your article

Submit your next manuscript at $\boldsymbol{\sim}$ springeropen.com 